\title{
CD 1252: HEALTH, QUALITY AND TOLERANCE TO PRE-HARVEST SPROUTING
}

\author{
CD 1252: SANIDADE, QUALIDADE E TOLERANCIA A GERMINAÇÃO \\ Volmir Sergio MARCHIORO² ${ }^{\text {; Francisco de Assis FRANCO' }}{ }^{1}$ \\ Tatiane DALLA NORA MONTECELLI ${ }^{1}$; Ivan SCHUSTER ${ }^{1}$; Mateus POLO ${ }^{3}$; \\ Fábio Junior Alcântara de LIMA ${ }^{3}$; Adriel EVANGELISTA ${ }^{3}$; Diego Augusto DOS SANTOS ${ }^{3}$; \\ Edson Luiz GRAVE ${ }^{3}$ \\ 1. Researcher, Agronomist, Doctor, COODETEC Desenvolvimento Produção e Comercialização Agrícola Ltda, BR 467, km 98, C.P. \\ 89, CEP 85813-450, Cascavel, PR, Brazil; 2. Volmir Sergio Marchioro, Engenheiro Agrônomo, Doutor. Universidade Federal de Santa \\ Maria, Frederico Westphalen, RS, Brazil. volmir@marchioro.eng.br; 3. Research assistant, Agronomist, COODETEC \\ Desenvolvimento Produção e Comercialização Agrícola Ltda, Cascavel, PR, Brazil.
}

\begin{abstract}
Resulting from the search for wheat cultivars with high yield potential, plant health, processing quality and tolerance to pre-harvest sprouting, CD 1252 was developed from the cross between cultivar IPR 85 and line OR1/3/BOW/GLENSON//BAGULA. Cultivar CD 1252 was tested in preliminary grain yield trials in 2005 and 2006, and then tested to determine the Value for Cultivation and Use (VCU) from 2007 to 2014, labelled CD 0711. All tests were arranged in an experimental design of randomized blocks, with three replications. The yield of cultivar CD 1252 was $5 \%$, $4 \%$ and $1 \%$ higher than the average yield of the two best controls, respectively, in the wheat-growing regions VCU 2, 3 and 4 . The wheat quality, potential for grain yield, and tolerance to pre-harvest sprouting of this cultivar are superior and it is tolerant to the main wheat diseases.
\end{abstract}

KEYWORDS: Triticum aestivum L. Diseases. Rain at harvest.

\section{INTRODUCTION}

Wheat breeding programs have significantly improved grain yield and other relevant traits (KOHLI, 1998), of which the processing quality has come to be a key factor in recent decades in Brazil. Currently, wheat breeding programs in Brazil are focused on the improvement of grain yield potential, processing quality and disease resistance.

For Mandarino (1993), the quality requirements were decisive for some improvements in wheat breeding programs because, aside from the traditional selection criteria (increased yield, and resistance to diseases and toxic elements), the grain quality traits, that are relevant for food processing and industry, have to be take into account in the development of new superior genotypes.

Quality maintenance at harvest is strongly related to tolerance to pre-harvest sprouting of a cultivar. Per Bassoi (2004), if rain falls before and during harvest, losses by germination are great, indicating the importance of using cultivars tolerant to pre-harvest sprouting in Brazil. To meet these essential prerequisites in the search for wheat lines with high quality, yield potential and pre-harvest sprouting tolerance, this study aimed to develop the CD 1252 cultivar.

\section{CONTENTS}

The CD 1252 cultivar was derived from the cross between cultivar IPR 85 and line OR1/3/BOW/GLENSON//BAGULA, made by COODETEC in 1999, in Palotina, State of Paraná. The $F_{1}$ seeds were sown in November 1999, in a greenhouse in Cascavel, producing $\mathrm{F}_{2}$ seeds. The $\mathrm{F}_{2}$ population was grown in 2000, in Cascavel, applying the mass selection method. The $\mathrm{F}_{3}, \mathrm{~F}_{4}$ and $\mathrm{F}_{5}$ populations were selected, respectively, in 2001, 2002 and 2003 by the pedigree method. In 2004, the $\mathrm{F}_{6}$ population was also selected by the pedigree method and the plots with regular plants were harvested in bulk, resulting in multiple sister lines. The best of these lines originated cultivar CD 1252. The pedigree of this line is CC15212-0T-3P-4P-9POP.

The CD 1252 cultivar was included in the preliminary trials of grain yield in Cascavel and Palotina, in 2005 and 2006. For its performing better than the controls, it was evaluated in tests of Value for Cultivation and Use (VCU), from 2007 to 2014, under the acronym CD 0711. The VCU tests were carried out at representative locations of the wheatgrowing regions (CUNHA et al., 2006). In the wheat-growing region 2, the VCU tests were conducted in Campo Mourão/PR, Cascavel/PR, Itapeva/SP, Itaberá/SP, and Taquarivaí/SP; in 
wheat-growing region 3, in Arapongas/PR, Goioerê/PR, Palotina/PR, Rolândia/PR, Dourados/MS, Maracaju/MS, Ponta Porã/MS, Manduri/SP, Palmital/SP, and in Santa Cruz do Rio Pardo/SP; and in the wheat-growing region 4, the tests were performed in Catalão/GO, Cristalina/GO, Luziânia/GO, Paracatu/MG, and in São Gotardo/MG.

The experiment was arranged in a randomized block design, with three replications, in plots consisting of six 5-m-long rows, spaced 0.20 $\mathrm{m}$ apart. The fertilization and pest and disease control were applied as officially recommenced (COMISSÃO, 2010). Prior to sowing, the seeds were treated with triadimenol and imidacloprid. The traits grain yield, days from emergence to heading, days from emergence to maturity, plant height, lodging, hectoliter weight, 1000-grain weight, gluten strength, and yield stability were assessed. At strategic locations, the genotype collections used in the VCU tests were planted, in which the observed shoot diseases, i.e., leaf rust, leaf spot, powdery mildew, head blight, scab and wheat mosaic virus, among other diseases, were not controlled.

A comparison of the mean grain yield in the wheat-growing regions $\mathrm{VCU} 2,3$ and 4, respectively, showed that the grain yield of the $\mathrm{CD}$ 1252 cultivar exceeded the average of the two best controls by $5 \%, 4 \%$ and $1 \%$ (Table 1). Due to the excellent performance of cultivar CD 1252, it was indicated for cultivation in the above regions, corresponding to the States of Parana, Mato Grosso do Sul, São Paulo, Mato Grosso, Goiás, Minas Gerais, and the Federal District (BRASIL, 2015).

Table 1. Mean grain yield $\left(\mathrm{kg} \mathrm{ha}^{-1}\right)$ of cultivar CD 1252 and the two best controls, in the VCU tests conducted in the wheat-growing regions of VCU 2, 3 and 4 of the states of Paraná, São Paulo, Mato Grosso do Sul, Goiás and Minas Gerais, from 2007 to 2014 - Cascavel/2015.

\begin{tabular}{|c|c|c|c|c|c|c|c|c|c|c|}
\hline$\overline{\text { Cultivar }}$ & 2007 & 2008 & 2009 & 2010 & 2011 & 2012 & 2013 & 2014 & Mean & $\%$ \\
\hline \multicolumn{11}{|c|}{ Wheat-growing region $\mathrm{VCU} 2$} \\
\hline$\overline{C D} 1252$ & 2931 & 4003 & 2677 & 4652 & 3696 & 3769 & 2878 & 5053 & 3707 & 105 \\
\hline $\mathrm{T} 1 *$ & 3023 & 3764 & 2572 & 4156 & 3168 & 3920 & 2732 & 5418 & 3669 & 104 \\
\hline $\mathrm{T} 2 *$ & 2559 & 3166 & 2504 & 3916 & 3258 & 3713 & 3014 & 5738 & 3408 & 96 \\
\hline Mean T & 2791 & 3465 & 2538 & 4036 & 3213 & 3817 & 2873 & 5578 & 3539 & 100 \\
\hline \multicolumn{11}{|c|}{ Wheat-growing region $\mathrm{V} \overline{C U} 3$} \\
\hline$\overline{\mathrm{CD} 1252}$ & 4166 & 3379 & 3193 & 2718 & 3461 & 2431 & 2332 & 2794 & 3059 & 104 \\
\hline $\mathrm{T} 1 *$ & 3924 & 3457 & 3245 & 2678 & 3193 & 2481 & 2294 & 2974 & 3045 & 103 \\
\hline $\mathrm{T} 2 *$ & 3610 & 3193 & 2853 & 2483 & 3199 & 2244 & 2429 & 2950 & 2856 & 97 \\
\hline Mean T & 3767 & 3325 & 3049 & 2580 & 3196 & 2362 & 2362 & 2962 & 2950 & 100 \\
\hline \multicolumn{11}{|c|}{ Wheat-growing region $\mathrm{VCU} 4$} \\
\hline$\overline{C D} 1252$ & 5345 & 5171 & 5023 & 5337 & 6042 & 5364 & 6379 & 5775 & 5555 & 101 \\
\hline $\mathrm{T} 1^{*}$ & 5293 & 5137 & 4760 & 5301 & 5596 & 5121 & 6261 & 6002 & 5434 & 98 \\
\hline $\mathrm{T} 2 *$ & 5328 & 4715 & 4752 & 5110 & 5900 & 5331 & 6523 & 6099 & 5470 & 99 \\
\hline Mean T & 5311 & 5137 & 4756 & 5206 & 5748 & 5226 & 6392 & 6435 & 5526 & 100 \\
\hline
\end{tabular}

*In the wheat-growing region of VCU 2 and VCU 3, in 2007, 2008, 2009 and 2010, the controls $\mathrm{T}_{1}$ and $\mathrm{T}_{2}$ were, respectively, BRS 208 and IPR 85, in 2011 and 2012 respectively, BRS Pardela and BRS Guamirim, and in 2013 and 2014, BRS Pardela and Mirante. In the VCU Region 4, in 2007 and 2008, the controls $\mathrm{T}_{1}$ and $\mathrm{T}_{2}$ were, respectively, CD 108 and BRS 210, in 2009, 2010 and 2011, respectively, CD 108 and BRS 264, CD 108 and CD 150, in 2012, the controls $\mathrm{T}_{1}$ and $\mathrm{T}_{2}$ were, respectively, BRS 207 and BRS 264, and in 2013 and 2014 the controls $\mathrm{T}_{1}$ and $\mathrm{T}_{2}$ were, respectively, CD 150 and BRS 264.

The CD 1252cultivar has a low average plant height (between $68-90 \mathrm{~cm}$, mean of $75 \mathrm{~cm}$ ). The cycle is average, lasting from 55 to 80 days from emergence to heading and 99 to 132 days from emergence to maturity (in the mean 66 and 116 days, respectively). CD 1252 has moderately resistant to lodging and to pre-harvest sprouting. In the means of the analysis of the processing quality of 32 samples from the tests in the different States, gluten strength was in the mean $340 \mathrm{~W}$ and stability 16.2 minutes, including CD 1252 in the extra strong wheat class.
In the experiments, carried out in the field from 2007 to 2014, data of several wheat diseases were recorded. $\mathrm{CD} 1252$ was classified as moderately resistant to powdery mildew (Blumeria graminis f.sp. tritici), leaf spots (Bipolares sorokiniana and Septoria tritici), glume blotch (Septoria nodorum), leaf rust (Puccinia triticina), and wheat blast (Pyricularia grisea). In view of the high disease incidence, the cultivar was classified as susceptible to head blight (Fusarium graminearum). Cultivar CD 1252 is classified as extra strong wheat, has a high yield potential, tolerance to pre-harvest 
sprouting and to the major wheat diseases. It represents a promising option for Brazilian wheat growers.

RESUMO: Buscando cultivares de potencial produtivo, sanidade, qualidade industrial e tolerância a germinação na espiga, foi desenvolvida a cultivar de trigo CD 1252, obtida do cruzamento entre a cultivar IPR 85 e a linhagem OR 1/3/BOW/GLENSON//BAGULA. A cultivar CD 1252, participou dos Ensaios Preliminares de rendimento de grãos em 2005 e 2006, sendo em seguida testada em Ensaios de Valor de Cultivo e Uso (VCU), nos anos de 2007 a 2014 , com a sigla CD 0711. Todos os ensaios foram conduzidos em delineamento experimental de blocos ao acaso, com três repetições. A cultivar $\mathrm{CD} 1252$ apresentou rendimento 5\%, 4\% e 1\% superior à média das duas melhores testemunhas, respectivamente, nas Regiões Tritícolas de VCU 2, 3 e 4. A referida cultivar tem qualidade superior (trigo melhorador), alto potencial de rendimento de grãos, tolerância à germinação na espiga e tolerância às principais doenças.

PALAVRAS-CHAVE: Triticum aestivum L. Doenças. Chuva na Colheita.

\section{REFERENCES}

BASSOI, M. C. Introdução ao problema da germinação pré-colheita em trigo no Brasil. In: CUNHA, G. R.; PIRES, J. L. F. (Ed.). Germinação pré-colheita em trigo. Passo Fundo: Embrapa Trigo. 2004. p. 21-136.

BRASIL. Serviço nacional de proteção de cultivares. Brasília: Ministério da Agricultura. Disponível em http://www.agricultura.gov.br/sarc/dfpv/lst1200.htm. Acesso em 20 maio de 2015.

BRUNETTA, D.; DOTTO, S. R. Trigo no Paraná: visão histórica, situação atual e perspectivas. In: CUNHA G. R. Trigo no Brasil Rumo ao Século XXI. Passo Fundo: Embrapa Trigo. 2000. p. 129-135.

COMISSÃO BRASILEIRA DE PESQUISA DE TRIGO E TRITICALE. Informações técnicas para a safra 2008: Trigo e Triticale. Londrina: Embrapa Soja, (Documento, 301). 2010. 147p.

CUNHA, G. R.; SCHEEREN, P. L.; PIRES, J. L. F.; MALUF, J. R. T.; PASINATO, A.; CAIERÃO, E.; SILVA, M. S.; DOTTO, S. R.; CAMPOS, L. A. C.; FELÍCIO, J. C.; CASTRO, R. L.; MARCHIORO, V.; RIEDE, C. R.; ROSA FILHO, O.; TONON, V. D.; SVOBODA, L. H. Regiões de adaptação para trigo no Brasil. Passo Fundo: Trigo Embrapa, (Circular Técnica Online, 20). 2006. 35p.

MANDARINO, J. M. G. Aspectos Importantes para a qualidade do Trigo. Documentos, 60. Londrina: Embrapa Soja. 1993. 32p.

KOHLI, M. M. Use of biotechnology in wheat breeding in the southern cone region. In: KOHLI, M. M.; FRANCIS, M. Application of biotechnologies to wheat breeding. Uruguai: Colônia., 1998. p.1-15.

PEÑA, R. J.; ORTIZ-MONASTEIRO, J. I.; SAYRE K. D. Estrategias para mejorar (o mantener) la calidad panadera en trigo de alto potencial em rendimiento. In: KOHLI M. M.; MARTINO D. L. Explorando altos rendimientos de trigo. Uruguay: Colonia. 1997. p. 289-306. 